\title{
Kajian Produktivitas Perikanan Tuna Cakalang Tongkol yang Tertangkap dengan Kapal Pukat Cincin (purse seine) 20 - 30 GT di Pelabuhan Perikanan Samudera Bitung
}

\author{
Productivity of Tuna, Skipjack, Tuna Frigate Catched by Purse Seiner 20 - 30 GT Landed in
} Bitung Oceanic Fishing Port

\author{
FRANSISCO WIBOWO PRASETYO*, LUSIA MANU dan REVOLS D.CH. PAMIKIRAN
}

Program Studi Pemanfaatan Sumberdaya Perikanan, Fakultas Perikanan dan Ilmu Kelautan, Universitas Sam Ratulangi, Manado 95115

\begin{abstract}
The purpose of this research is to distinguish the productivity of purse seiner 20 - 30 GT and the fluctuation of Tuna, Skipjack and Tuna frigate landed in Bitung Ocean Fishing Port for the period of 2011 to 2015. Survey method with descriptive approach was applied in this research. The result indicated that the production reached the peak on 2011 to 2012 and subsequently decreased until 2015. In general, the production of every single purse seiner has shown a tendency to increase.
\end{abstract}

Keywords : productivity, tuna, skipjack, tuna frigate, purse seiner, Bitung.

\begin{abstract}
ABSTRAK
Penelitian ini bertujuan mengetahui produktivitas kapal dan fluktuasi hasil tangkapan ikan Tuna, Cakalang, Tongkol yang menggunakan kapal purse seine 20 - 30 GT di Pelabuhan Perikanan Samudera Bitung untuk periode tahun 2011 sampai 2015. Penelitian ini dilakukan berdasarkan metode survei dengan pendekatan secara deskriptif. Puncak produksi terjadi pada tahun 2011 sampai tahun 2012 dan selanjutnya mengalami penurunan sampai tahun 2015. Perkembangan produksi per trip secara umum dari setiap kapal menunjukkan kecenderungan untuk naik.
\end{abstract}

Kata-kata kunci: produktivitas, tuna, cakalang, tongkol, kapal purse seine, Bitung.

\section{PENDAHULUAN}

Produksi hasil tangkapan ikan di Pelabuhan Perikanan Samudra (PPS) Bitung dikontribusi oleh kapal penangkap yang umumnya menggunakan alat tangkap pukat cincin, pukat pantai, jaring insang, huhate dan pancing ulur (Laporan Statistik PPS Bitung, 2015). Dari berbagai jenis ikan tangkapan yang didaratkan di PPS Bitung, Tuna, Cakalang, dan Tongkol (TCT) menjadi komoditas utama untuk meningkatkan industrialisasi perikanan tangkap yang telah ditunjukan oleh sebagian besar masyarakat pesisir yang memiliki pekerjaan sebagai nelayan baik pada usaha penangkapan, pengolahan, perdagangan

\footnotetext{
*Penulis untuk penyuratan; e-mail: manulusia@yahoo.com
}

maupun industri penunjang. Oleh karena itu Tuna, Tongkol, dan Cakalang memainkan peran penting dalam meningkatkan pembangunan perikanan di Indonesia.

Komoditas yang dihasilkan, TCT memberikan konstribusi yang besar dalam hasil ekspor perikanan di indonesia. Perikanan TCT juga merupakan industri yang harus diperhatikan perkembangannya karena melibatkan semua produk utama mulai dari segar atau beku, maupun olahan produk ikan kaleng. Sehingga untuk kedepannya perikanan Indonesia bisa mampu memenuhi tuntutan pasar internasional dalam kegiatan ekspor yang berguna untuk tambahan devisa negara terutama untuk keseimbangan neraca perdagangan luar negeri. Devisa yang masuk 
juga akan menyebabkan peningkatan kesejateraan penduduk terutama masyarakat Sulawesi Utara (Direktorat Jenderal Pengolahan Hasil Perikanan, 2012).

Pertumbuhan volume produksi ikan TCT di PPS Bitung berfluktuasi dalam lima tahun terakhir (2011 - 2015). Oleh karena itu, kajian tentang produksi hasil tangkapan TCT dan produktivitas kapal purse seine berukuran 15-30 GT perlu diketahui guna peningkatan dan pengelolaan sumberdaya TCT yang berkelanjutan.

\section{METODE PENELITIAN}

Penelitian ini dilakukan berdasarkan metode survei dengan pendekatan secara deskriptif. Data primer diperoleh langsung dari subjek penelitian dengan menggunakan alat pengukuran atau alat pengambilan data langsung pada subjek sebagai sumber informasi yang dicari. Sedangkan, data sekunder adalah data dokumentasi dan laporan yang diambil dari PPS Bitung.

Analisis data teknis unit penangkapan Purse Seine didasarkan pada faktor dan efisiensi teknis dari unit penangkapan ikan. Analisis faktor teknis berupa ukuran kapal Purse Seine digunakan untuk analisis produktivitas, dan data jumlah trip untuk menganalisis perkembangan produksi. Perkembangan produksi dianalisa secara deskriptif kemudian dibandingkan tiap hasil tangkapan kapal satu dengan kapal yang lain.

Menurut Setyorini $d k k$ (2009) pengukuran produktivitas dari alat tangkap ikan meliputi produktivitas per unit alat tangkap, per orang dan per trip penangkapan. Adapun formula yang digunakan adalah sebagai berikut:

Produktivitas $=\frac{j \text { lh hasil tangkapan dalam } 1 \text { (satu) tahun }}{\text { Trip Penangkapan }}$

Produktivitas kapal penangkap ikan TCT per tahun dapat dicari dengan berdasarkan keputusan Menteri Kelautan Dan Perikanan Republik Indonesia Nomor 61/KEPMEN-KP/2014, produktivitas dinilai dengan formula:
Produktivitas $=\frac{\text { jlh hasil tangkapan dalam } 1 \text { (satu) tahun }}{\text { GT kapal }}$

Produktivitas kapal penangkap ikan sebagaimana dimaksud ditetapkan per Gross Tonnage (GT) per tahun berdasarkan perhitungan jumlah hasil tangkapan ikan perkapal dalam 1 (satu) tahun dibagi besarnya GT kapal yang bersangkutan.

\section{HASIL DAN PEMBAHASAN}

Unit kapal penangkapan Purse Seine 20 30 GT di PPS Bitung, Kota Bitung berjumlah 24 unit dan untuk sampel pengamatan dalam penelitian ini menggunakan 12 kapal Purse Seine 20 - 30 GT seperti disajikan pada Tabel 1 dan untuk produksinya selama periode 5 tahun (2011 2015) disajikan pada Tabel 2.

Tabel 2 menggambarkan produksi TCT dengan menggunakan kapal Purse Seine berukuran 20-30 GT untuk periode tahun 2011-2015. Hasil produksi TCT pada tahun 2011 sebesar $945.907 \mathrm{~kg}$, dan pada tahun 2012 meningkat sebanyak $973.020 \mathrm{~kg}$, dan menurun ditahun 2013 dan 2014 menjadi $938.500 \mathrm{~kg}$ dan $691.870 \mathrm{~kg}$, dan meningkat kembali pada tahun 2015 menjadi 906.923 $\mathrm{kg}$.

Gambar 1 dapat dilihat bahwa perkembangan produksi KM. Yapan Star-01 mengalami peningkatan pada tahun 20112012 dan menurun pada tahun 2013-2014 kemudian meningkat kembali ditahun 2015. Lain halnya dengan KM. Putri Laut-07 yang mengalami penurunan produksi pada tahun 2011-2012 dan meningkat secara perlahan pada tahun 2013-2015. Sama halnya dengan KM. Yapan Star-01, KM. Jerusalem juga mengalami peningkatan ditahun 2011-2012, sementara KM. Melstesye terjadi penurunan produksi pada tahun 2011-2012 dan mengalami peningkatan yang signifikan pada tahun 2015 .

Untuk perkembangan produksi oleh KM. Sari Usaha-02 mengalami peningkatan 2011-2013, dan mengalami penurunan yang signifikan pada tahun 2014-2015. 
Tabel 1. Daftar kapal Purse Seine 20 - 30 GT di PPS Bitung yang diteliti.

\begin{tabular}{|c|c|c|c|c|c|}
\hline $\begin{array}{l}\mathrm{N} \\
\mathrm{o}\end{array}$ & NAMA KAPAL & GT & $\begin{array}{l}\text { UKURAN } \\
\text { KAPAL } \\
\text { LOA }(m)\end{array}$ & $\begin{array}{c}\text { MESIN } \\
\text { PENGGERAK } \\
\text { KAPAL }\end{array}$ & $\begin{array}{l}\text { KEKUATAN } \\
\text { MESIN (PK) }\end{array}$ \\
\hline 1 & KM. YAPAN STAR - 01 & 23 & 18,40 & MITSUBISHI & 80 \\
\hline 2 & KM. PUTRI LAUT - 07 & 28 & 20,30 & MITSUBISHI & 315 \\
\hline 3 & KM. JERUSALEM & 28 & 22,00 & NISSAN & 150 \\
\hline 4 & KM. MELSTESYE & 28 & 19,50 & MITSUBISHI & 380 \\
\hline 5 & KM. RATU ROSARI -01 & 28 & 19,12 & MITSUBISHI & 240 \\
\hline 6 & KM. AL -ANSHAR & 29 & 21,00 & MITSUBISHI & 315 \\
\hline 7 & KM. PUTRI VITA & 29 & 19,00 & MITSUBISHI & 220 \\
\hline 8 & KM. ARDILAH - 03 & 29 & 20,42 & MITSUBISHI & 220 \\
\hline 9 & KM. SARI USAHA - 02 & 29 & 22,00 & NISSAN & 240 \\
\hline 10 & KM. ALBAKOR & 29 & 17,71 & YANMAR & 255 \\
\hline 11 & KM. ADAM PUTRA -01 & 29 & 21,20 & MITSUBISHI & 70 \\
\hline 12 & KM. GENESARET - 03 & 30 & 24,10 & WEICHAI & 450 \\
\hline
\end{tabular}

Tabel 2. Jumlah produksi 12 kapal selama periode 5 tahun.

\begin{tabular}{|c|c|c|c|c|c|c|c|c|c|c|c|c|}
\hline \multirow{3}{*}{ NO } & \multirow{3}{*}{ NAMA KAPAL } & \multirow{3}{*}{ GT } & \multicolumn{10}{|c|}{ PRODUKSI TCT DENGAN KAPAL PURSE SEINE 20-30 GT DI PPS BITUNG } \\
\hline & & & \multicolumn{2}{|c|}{ TAHUN 2011} & \multicolumn{2}{|c|}{ TAHUN 2012} & \multicolumn{2}{|c|}{ TAHUN 2013} & \multicolumn{2}{|c|}{ TAHUN 2014} & \multicolumn{2}{|c|}{ TAHUN 2015} \\
\hline & & & Trip & $\begin{array}{l}\text { Produksi } \\
(\mathrm{kg})\end{array}$ & Trip & $\begin{array}{l}\text { Produksi } \\
\text { (kg) }\end{array}$ & Trip & $\begin{array}{l}\text { Produksi } \\
(\mathrm{kg})\end{array}$ & Trip & $\begin{array}{l}\text { Produksi } \\
\text { (kg) }\end{array}$ & Trip & $\begin{array}{l}\text { Produksi } \\
(\mathrm{kg})\end{array}$ \\
\hline 1 & $\begin{array}{l}\text { KM. YAPAN STAR- } \\
01\end{array}$ & 23 & 48 & 153140 & 44 & 154750 & 21 & 34500 & 22 & 57600 & 37 & 84050 \\
\hline 2 & $\begin{array}{l}\text { KM. PUTRI LAUT- } \\
07\end{array}$ & 28 & 15 & 1800 & 11 & 2000 & 82 & 32100 & 99 & 113520 & 103 & 99550 \\
\hline 3 & KM. JERUSALEM & 28 & 23 & 102000 & 23 & 107300 & 18 & 71000 & 15 & 64900 & 8 & 28812 \\
\hline 4 & KM. MELSTESYE & 28 & 9 & 30617 & 9 & 30800 & 17 & 85220 & 14 & 61630 & 25 & 144024 \\
\hline 5 & $\begin{array}{l}\text { KM. RATU ROSARI } \\
-01\end{array}$ & 28 & 13 & 16000 & 13 & 17000 & 34 & 46250 & 33 & 81550 & 41 & 46501 \\
\hline 6 & KM. AL - ANSHAR & 29 & 55 & 151350 & 55 & 154250 & 42 & 90660 & 24 & 46660 & 43 & 47640 \\
\hline 7 & KM. PUTRI VITA & 29 & 20 & 28800 & 20 & 28800 & 45 & 61168 & 11 & 4740 & 115 & 130400 \\
\hline 8 & KM. ARDILAH - 03 & 29 & 45 & 118200 & 45 & 120150 & 12 & 56080 & 39 & 69670 & 39 & 185010 \\
\hline 9 & $\begin{array}{l}\text { KM. SARI USAHA - } \\
02\end{array}$ & 29 & 28 & 191600 & 28 & 200150 & 19 & 188610 & 9 & 25250 & 10 & 27000 \\
\hline 10 & KM. ALBAKOR & 29 & 16 & 70600 & 16 & 72150 & 19 & 71810 & 7 & 17600 & 12 & 27289 \\
\hline 11 & $\begin{array}{l}\text { KM. ADAM PUTRA } \\
-01\end{array}$ & 29 & 27 & 71000 & 27 & 72820 & 35 & 60320 & 10 & 57500 & 18 & 29877 \\
\hline \multirow[t]{3}{*}{12} & $\begin{array}{l}\text { KM. GENESARET - } \\
03\end{array}$ & 30 & 4 & 10800 & 4 & 12850 & 49 & 140782 & 34 & 91250 & 30 & 56770 \\
\hline & Jum. Total Per & ahun & 303 & 945907 & 295 & 973020 & 393 & 938500 & 317 & 691870 & 481 & 906923 \\
\hline & Jum. Rata- ra & a/thn & 25 & 78825.5 & 24.5 & 81085 & 33 & 78208.3 & 26 & 57655.83 & 40 & 75576.92 \\
\hline
\end{tabular}




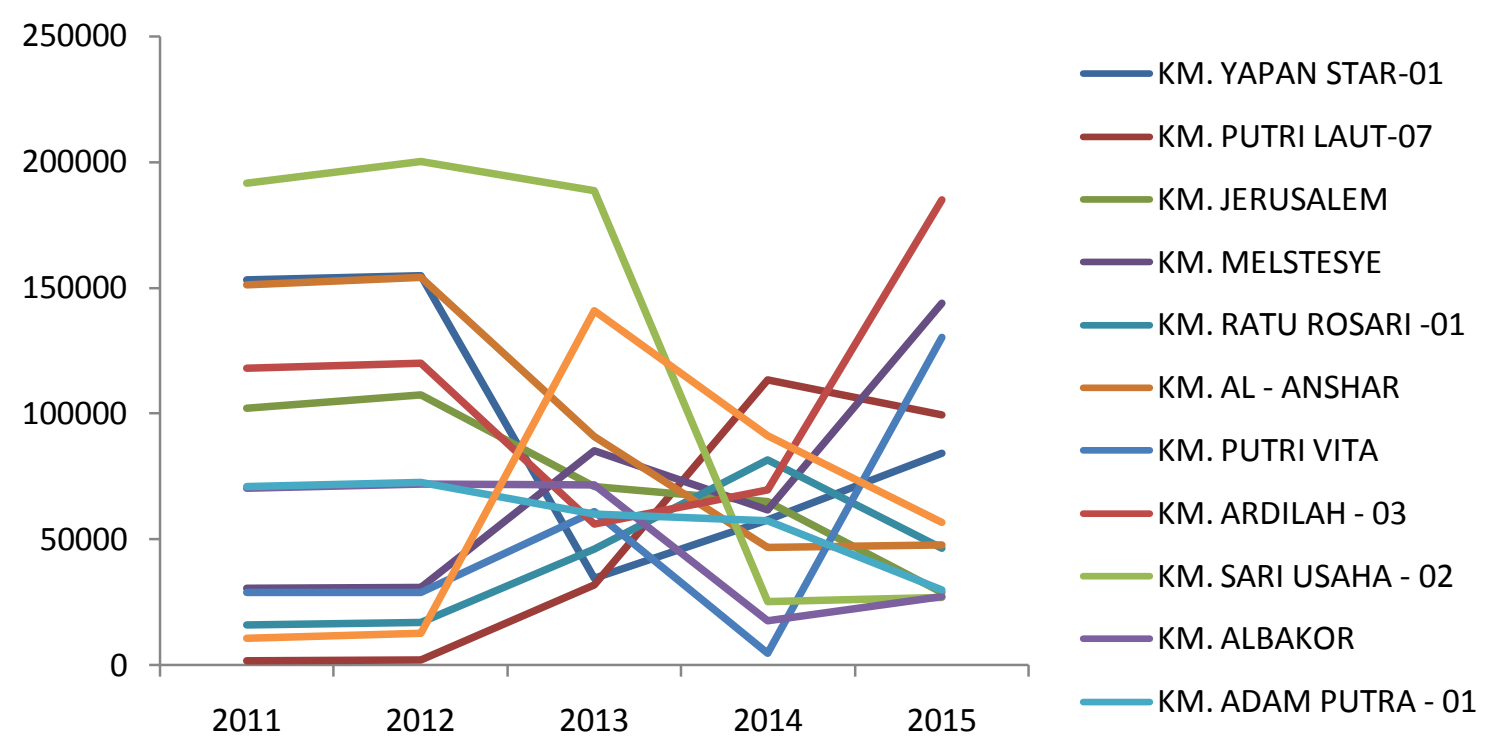

Gambar 1. Produksi 12 kapal purse seine 20 - 30 GT selama 5 tahun beroperasi

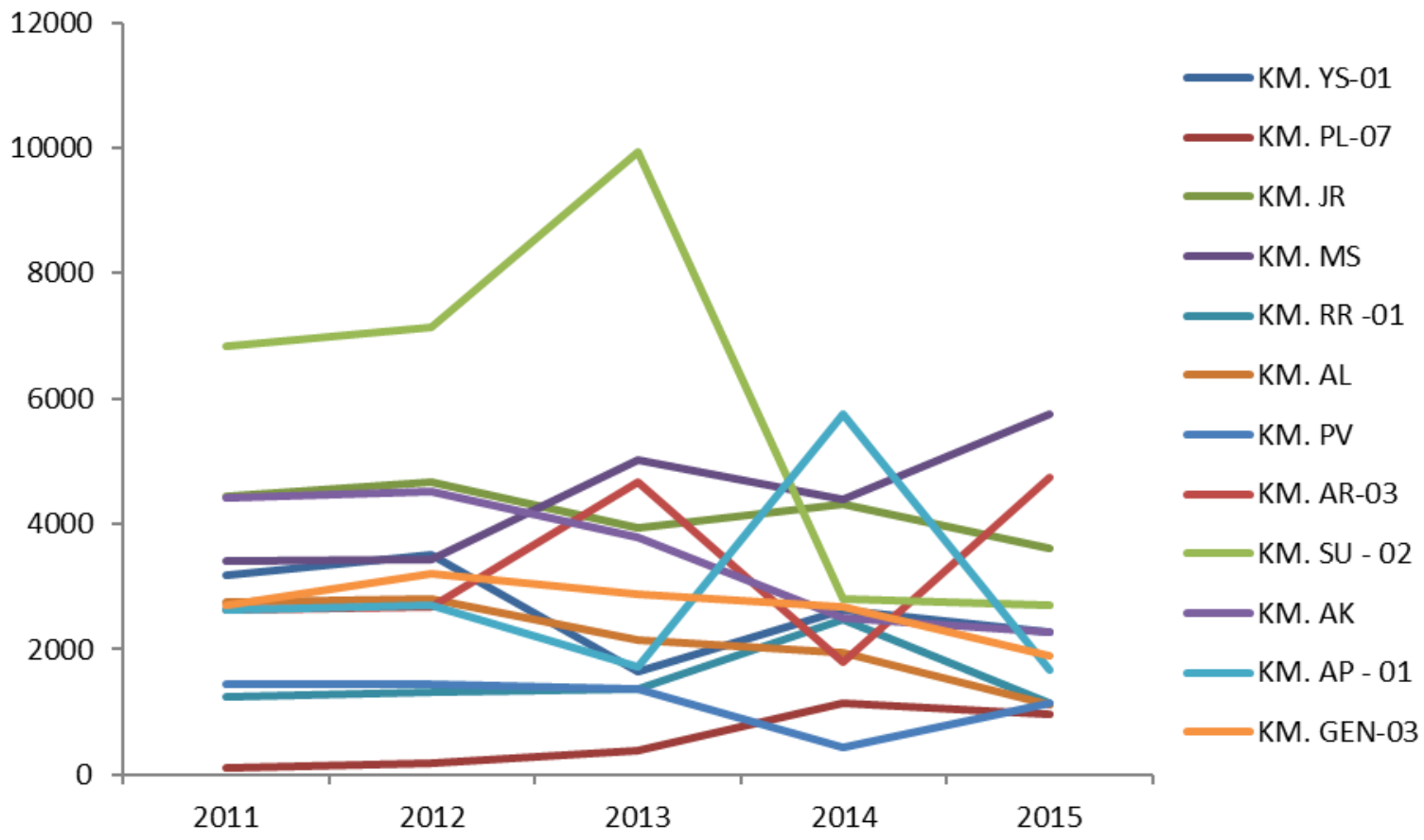

Gambar 2. Produktivitas 12 Kapal Purse Seine 20 - 30 GT Selama 5 Tahun beroperasi

Sementara KM. Albakor dan KM. Adam Putra-01 hampir mempunyai nilai produksi yang sama yaitu pada tahun 2011-2013. Berbeda dengan KM. Genesaret yang mengalami naik turun dan hanya mengalami peningkatan yang signifikan pada tahun 2013.

Perkembangan produksi TCT yang menggunakan kapal Purse Seine 20-30 GT mengalami fluktuasi dalam hal produktivitas dimana dipengaruhi oleh beberapa faktor seperti peran pemerintah yang mengeluarkan kebijakan untuk mengurangi atau membatasi tenaga kerja asing sehingga produktivitas pun ikut mengalami penurunan. 
F.W. Prasetyo dkk

Tabel 3. Produksi/Trip TCT dengan Kapal Purse Seine 20 - 30 GT di PPS Bitung yang diteliti.

\begin{tabular}{|c|c|c|c|c|c|c|c|c|c|c|c|c|c|c|c|c|}
\hline \multirow{3}{*}{ No } & \multirow{3}{*}{ NAMA KAPAL } & \multicolumn{15}{|c|}{ PRODUKSI KAPAL PURSE SEINE 20 -30 GT DI PPS BITUNG } \\
\hline & & \multicolumn{3}{|c|}{ TAHUN 2011} & \multicolumn{3}{|c|}{ TAHUN 2012} & \multicolumn{3}{|c|}{ TAHUN 2013} & \multicolumn{3}{|c|}{ TAHUN 2014} & \multicolumn{3}{|c|}{ TAHUN 2015} \\
\hline & & Trip & $\begin{array}{l}\text { Produksi } \\
(\mathrm{kg})\end{array}$ & $\begin{array}{l}\text { Produksi } \\
\text { per trip } \\
(\mathrm{kg})\end{array}$ & Trip & $\begin{array}{l}\text { Produksi } \\
(\mathrm{kg})\end{array}$ & $\begin{array}{l}\text { Produksi } \\
\text { per trip } \\
(\mathrm{kg})\end{array}$ & Trip & $\begin{array}{l}\text { Produksi } \\
(\mathrm{kg})\end{array}$ & $\begin{array}{l}\text { Produksi } \\
\text { per } \quad \text { trip } \\
(\mathrm{kg})\end{array}$ & Trip & $\begin{array}{l}\text { Produksi } \\
(\mathrm{kg})\end{array}$ & $\begin{array}{l}\text { Produksi } \\
\text { per } \quad \text { trip } \\
(\mathrm{kg})\end{array}$ & Trip & $\begin{array}{l}\text { Produksi } \\
(\mathrm{kg})\end{array}$ & $\begin{array}{l}\text { Produksi } \\
\text { per trip } \\
(\mathrm{kg})\end{array}$ \\
\hline 1 & KM. YAPAN STAR-01 & 48 & 153140 & 3190.42 & 44 & 154750 & 3517.05 & 21 & 34500 & 1642.86 & 22 & 57600 & 2618.18 & 37 & 84050 & 2271.62 \\
\hline 2 & KM. PUTRI LAUT-07 & 15 & 1800 & 120 & 11 & 2000 & 181.818 & 82 & 32100 & 391.463 & 99 & 113520 & 1146.67 & 103 & 99550 & 966.505 \\
\hline 3 & KM. JERUSALEM & 23 & 102000 & 4434.78 & 23 & 107300 & 4665.22 & 18 & 71000 & 3944.44 & 15 & 64900 & 4326.67 & 8 & 28812 & 3601.5 \\
\hline 4 & KM. MELSTESYE & 9 & 30617 & 3401.89 & 9 & 30800 & 3422.22 & 17 & 85220 & 5012.94 & 14 & 61630 & 4402.14 & 25 & 144024 & 5760.96 \\
\hline 5 & KM. RATU ROSARI -01 & 13 & 16000 & 1230.77 & 13 & 17000 & 1307.69 & 34 & 46250 & 1360.29 & 33 & 81550 & 2471.21 & 41 & 46501 & 1134.17 \\
\hline 6 & KM. AL - ANSHAR & 55 & 151350 & 2751.82 & 55 & 154250 & 2804.55 & 42 & 90660 & 2158.57 & 24 & 46660 & 1944.17 & 43 & 47640 & 1107.91 \\
\hline 7 & KM. PUTRI VITA & 20 & 28800 & 1440 & 20 & 28800 & 1440 & 45 & 61168 & 1359.29 & 11 & 4740 & 430.909 & 115 & 130400 & 1133.91 \\
\hline 8 & KM. ARDILAH - 03 & 45 & 118200 & 2626.67 & 45 & 120150 & 2670 & 12 & 56080 & 4673.33 & 39 & 69670 & 1786.41 & 39 & 185010 & 4743.85 \\
\hline 9 & KM. SARI USAHA - 02 & 28 & 191600 & 6842.86 & 28 & 200150 & 7148.21 & 19 & 188610 & 9926.84 & 9 & 25250 & 2805.56 & 10 & 27000 & 2700 \\
\hline 10 & KM. ALBAKOR & 16 & 70600 & 4412.5 & 16 & 72150 & 4509.38 & 19 & 71810 & 3779.47 & 7 & 17600 & 2514.29 & 12 & 27289 & 2274.08 \\
\hline 11 & $\begin{array}{l}\text { KM. ADAM PUTRA - } \\
01\end{array}$ & 27 & 71000 & 2629.63 & 27 & 72820 & 2697.04 & 35 & 60320 & 1723.43 & 10 & 57500 & 5750 & 18 & 29877 & 1659.83 \\
\hline 12 & KM. GENESARET - 03 & 4 & 10800 & 2700 & 4 & 12850 & 3212.5 & 49 & 140782 & 2873.1 & 34 & 91250 & 2683.82 & 30 & 56770 & 1892.33 \\
\hline & JUMLAH & 303 & 945907 & 35781 & 295 & 973020 & 37576 & 393 & 938500 & 38846 & 317 & 691870 & 32880 & 481 & 906923 & 29247 \\
\hline
\end{tabular}


F.B. Prasetyo dll.

Tabel 4. Produksi/GT TCT dengan Kapal Purse Seine 20-30 GT di PPS Bitung yang diteliti.

\begin{tabular}{|c|c|c|c|c|c|c|c|c|c|c|c|c|}
\hline \multirow{3}{*}{ No } & \multirow{3}{*}{ NAMA KAPAL } & \multirow{3}{*}{ GT } & \multicolumn{10}{|c|}{ PRODUKSI/GT TCT DENGAN KAPAL PURSE SEINE 20-30 GT DI PPS BITUNG } \\
\hline & & & \multicolumn{2}{|l|}{ TAHUN 2011} & \multicolumn{2}{|l|}{ TAHUN 2012} & \multicolumn{2}{|l|}{ TAHUN 2013} & \multicolumn{2}{|l|}{ TAHUN 2014} & \multicolumn{2}{|l|}{ TAHUN 2015} \\
\hline & & & Produksi (kg) & Produkt $(\mathrm{kg})$ & Produksi (kg) & Produkt $(\mathrm{kg})$ & Produksi $(\mathrm{kg})$ & Produkt $(\mathrm{kg})$ & Produksi $(\mathrm{kg})$ & Produkt $(\mathrm{kg})$ & Produksi $(\mathrm{kg})$ & Produkt $(\mathrm{kg})$ \\
\hline 1 & KM. YAPAN STAR-01 & 23 & 153140 & 6658.26 & 154750 & $6,728.26$ & 34500 & $1,500.00$ & 57600 & $2,504.35$ & 84050 & 3654.35 \\
\hline 2 & KM. PUTRI LAUT-07 & 28 & 1800 & 64.2857 & 2000 & 71.43 & 32100 & $1,146.43$ & 113520 & $4,054.29$ & 99550 & 3555.36 \\
\hline 3 & KM. JERUSALEM & 28 & 102000 & 3642.86 & 107300 & $3,832.14$ & 71000 & $2,535.71$ & 64900 & $2,317.86$ & 28812 & 1029 \\
\hline 4 & KM. MELSTESYE & 28 & 30617 & 1093.46 & 30800 & $1,100.00$ & 85220 & $3,043.57$ & 61630 & $2,201.07$ & 144024 & 5143.71 \\
\hline 5 & KM. RATU ROSARI -01 & 28 & 16000 & 571.429 & 17000 & 607.14 & 46250 & $1,651.79$ & 81550 & $2,912.50$ & 46501 & 1660.75 \\
\hline 6 & KM. AL - ANSHAR & 29 & 151350 & 5218.97 & 154250 & $5,318.97$ & 90660 & $3,126.21$ & 46660 & $1,608.97$ & 47640 & 1642.76 \\
\hline 7 & KM. PUTRI VITA & 29 & 28800 & 993.103 & 28800 & 993.10 & 61168 & $2,109.24$ & 4740 & 163.45 & 130400 & 4496.55 \\
\hline 8 & KM. ARDILAH - 03 & 29 & 118200 & 4075.86 & 120150 & $4,143.10$ & 56080 & $1,933.79$ & 69670 & $2,402.41$ & 185010 & 6379.66 \\
\hline 9 & KM. SARI USAHA - 02 & 29 & 191600 & 6606.9 & 200150 & $6,901.72$ & 188610 & $6,503.79$ & 25250 & 870.69 & 27000 & 931.034 \\
\hline 10 & KM. ALBAKOR & 29 & 70600 & 2434.48 & 72150 & $2,487.93$ & 71810 & $2,476.21$ & 17600 & 606.90 & 27289 & 941 \\
\hline 11 & KM. ADAM PUTRA - 01 & 29 & 71000 & 2448.28 & 72820 & $2,511.03$ & 60320 & $2,080.00$ & 57500 & $1,982.76$ & 29877 & 1030.24 \\
\hline \multirow[t]{3}{*}{12} & KM. GENESARET - 03 & 30 & 10800 & 360 & 12850 & 428.33 & 140782 & $4,692.73$ & 91250 & $3,041.67$ & 56770 & 1892.33 \\
\hline & Jumlah Per Tahun & & 945907 & 34167.9 & 973020 & 35123.2 & 938500 & 32799.5 & 691870 & 24666.9 & 906923 & 32356.7 \\
\hline & Jumlah Rata-rata Per tah & & 78825.58 & 2847.32 & 81085 & 2926.93 & 78208.33 & 2733.29 & 57655.83 & 2055.58 & 75576.92 & 2696.4 \\
\hline
\end{tabular}


Produksi/Trip TCT dengan kapal Purse Seine 20 - 30 GT di PPS Bitung yang diteliti dapat dilihat pada Tabel 3. Produksi/ trip tahun 2011 sebanyak $35.781 \mathrm{~kg}$, dan mengalami peningkatan sedikit untuk tahun 2012 dan 2013 sebanyak $38.846 \mathrm{~kg}$, dan terjadi penurunan pada tahun 2015 mencapai $29.247 \mathrm{~kg}$ produksi pertrip.

Gambar 2 menjelaskan perkembangan produksi pertrip yang dimana KM. Jerusalem dan KM. Melstesye memperlihatkan peningkatan tiap tahunnya dibandingkan dengan KM. Putri Laut-07 yang mengalami penurunanproduktivitas. KM. Ardilah-03 mengalami peningkatan dan penurunan yang signifikan pada tahun 20122014. Sementara kapal KM. Putri Vita yang mengalami penurunan pada tahun 2014. KM. Sari Usaha mengalami peningkatan pada tahun 2011-2013 dan terjadi penurunan pada tahun 2014-2015. Sementara KM. Adam Putra-01 pada tahun 2014 mengalami peningkatan namun terjadi penurunan pada tahun 2015 .

Hasil kajian untuk ke-12 kapal purse seine ini, dapat dilihat bahwa pada KM. Melstesye dan KM. Ardilah mengalami peningkatan yang signifikan pada perkembangan produksi pertrip tiap tahunnya.
Tabel 4 menggambarkan fluktuasi produksi/GT TCT dengan kapal Purse Seine 20-30 GT di PPS Bitung, dimana pada tahun 2011 didapatkan sebanyak $34167.9 \mathrm{~kg}$, dan pada tahun 2012 meningkat menjadi $35123.2 \mathrm{~kg}$, dan mengalami penurunan pada tahun 2013 dan tahun 2014 menjadi $32799.2 \mathrm{~kg}$ dan $24666.9 \mathrm{~kg}$, dan terjadi sedikit peningkatan pada tahun 2015 menjadi $32356.7 \mathrm{~kg}$.

Gambar 3 dapat dilihat bahwa produksi KM. Yapan Star 01 mengalami peningkatan pada tahun 2011-2012 dan turun pada tahun 2013. Sedangkan KM. Melstesye mengalami penurunan pada tahun 2011-2012 dan meningkat pada tahun 2015. Pada KM. Jerusalem mengalami penurunan pada tahun 2015 dan pada KM. Putri laut-07 mengalami penurunan pada tahun 2011-2012.

Perkembangan produksi pada KM. Ardilah-03 mengalami naik turun dan terjadi peningkatan yang signifikan pada tahun 2015 dan diikuti oleh KM. Putri vita yang mengalami peningkatan pada tahun 2015. Untuk kapal KM. Al-anshar ditahun 20112012 mengalami peningkatan namun menurun kembali ditahun 2013-2015. Untuk KM. Ratu Rosari-01 berada ditingkat terendah dari ketiga kapal yaitu kapal KM. Ardilah-03, KM. Putri vita, dan KM. Alanshar.

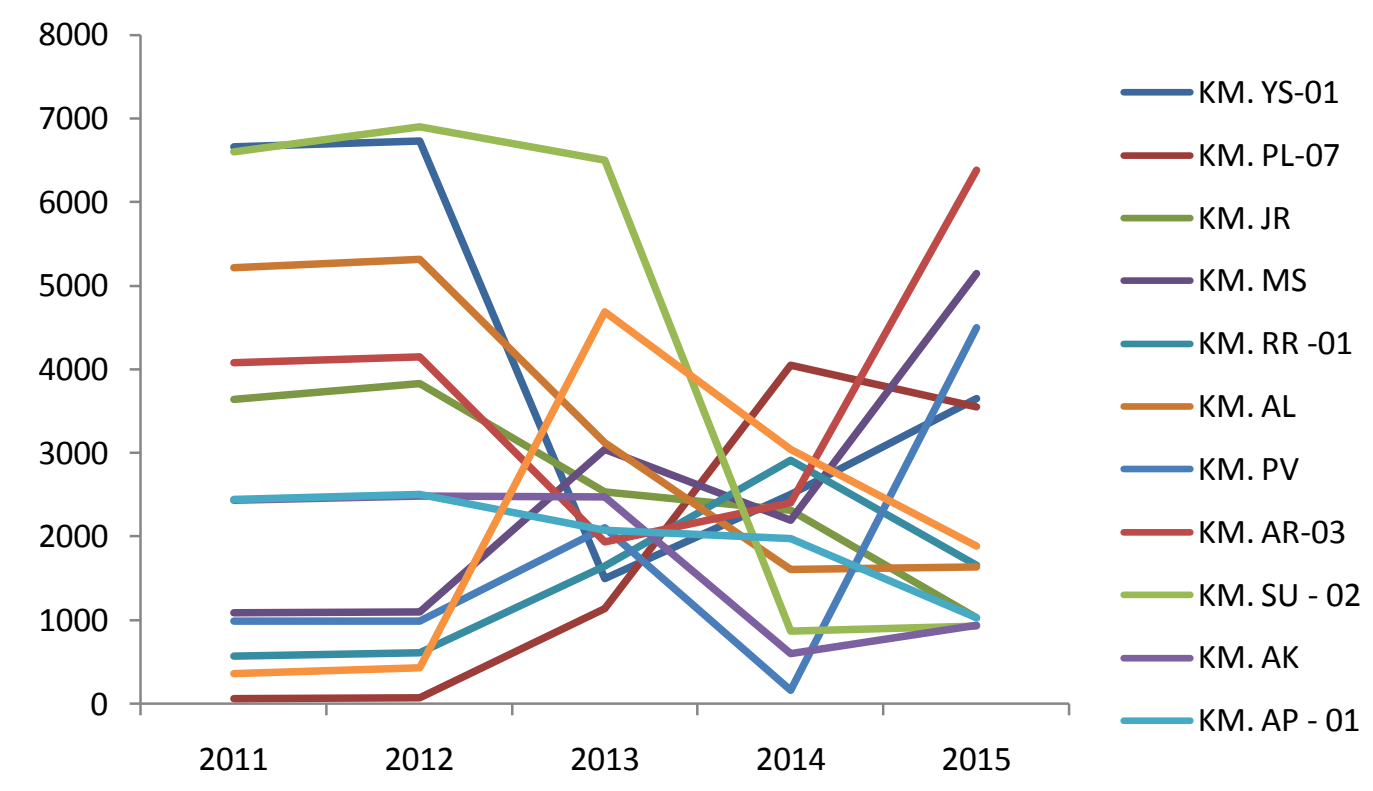

Gambar 3. Produktivitas (Produksi dibagi GT) 12 Kapal Purse Seine 20 - 30 GT Selama 5 Tahun beroperasi 
Untuk KM. Albakor dan KM Adam Putra-01 memperoleh hasil yang hampir sama pada tahun 2011-2012. Sedangkan KM. Sari Usaha-02 mengalami peningkatan ditahun 2011-2013 dan terjadi penurunan pada tahun 2014 dan 2015 dan pada KM. Genesaret-03 mengalami naik turun dalam perolehan hasil produksi.

Dari keseluruhan ke 12 kapal tersebut menunjukkan bahwa masing-masing kapal mempunyai hasil produksi yang bervariasi tiap tahunnya, ada yang meningkat dan ada yang menurun sehingga capaian hasil produksi periode 2011 - 2015 berfluktuatif.

Nilai Produktivitas masing-masing kapal setiap tahun yang dikemukakan pada (Gambar 3), menjadi dasar untuk pengelompokkan kapal dengan nilai Produktivitas di bawah rata - rata dan di atas rata - rata yang disajikan pada (Tabel 3) sesuai dengan Kepmen KP No.61 tahun 2014 untuk alat tangkap Purse Seine sebesar 3,0 dalam satuan ton atau 3.000 dalam satuan $\mathrm{Kg}$ untuk membandingkan tingkat produktivitas hasil tangkapan Purse Seine. Dari pengamatan Tabel 5 menunjukkan bahwa pada tahun 2011 produktivitas diatas nilai standar rata-rata tercatat sebanyak 5 kapal dan dibawah nilai standar rata-rata sebanyak 7 kapal. Sama halnya dengan tahun 2011 dan tahun 2012 tercatat sebanyak 5 kapal diatas nilai standar rata-rata dan 7 kapal dibawah nilai standar rata - rata. Dan pada tahun 2013 tercatat sebanyak 4 kapal yang memiliki nilai standar diatas rata-rata dan 8 kapal dibawah nilai standar. Untuk tahun 2014 tercatat 2 kapal diatas nilai standar dan 10 kapal dibawah nilai standar. Dan tahun 2015 tercatat sebanyak 5 kapal diatas nilai standar dan 7 kapal dibawah nilai standar.

Hasil analisis menunjukkan terdapat 9 kapal purse seine yang nilai produktivitasnya diatas standar selama periode tahun 2011-2015 yaitu; KM. Yapan Star-01, KM. Jerusalem, KM. Al - Anshar, KM. Ardilah - 03, KM. Sari Usaha - 02, KM. Melstesye, KM. Genesaret - 03, KM. Putri Laut-07, KM. Putri Vita. Sedangkan kapal yang tidak produktif adalah KM. Ratu Rosari -01, KM. Albakor dan KM. Adam Putra -01 .

Tabel 5. Nilai Produktivitas setiap kapal setiap tahun.

\begin{tabular}{|c|c|c|c|c|c|c|c|c|c|c|c|}
\hline \multirow{3}{*}{ NO } & \multirow{3}{*}{ NAMA KAPAL } & \multicolumn{10}{|l|}{ TAHUN } \\
\hline & & \multicolumn{2}{|l|}{2011} & \multicolumn{2}{|l|}{2012} & \multicolumn{2}{|l|}{2013} & \multicolumn{2}{|l|}{2014} & \multicolumn{2}{|l|}{2015} \\
\hline & & Kg & Ton & $\mathbf{K g}$ & Ton & $\mathbf{K g}$ & Ton & Kg & Ton & $\mathbf{K g}$ & Ton \\
\hline 1 & KM. YAPAN STAR-01 & 6658.26 & 6,65 & $6,728.26$ & 6,72 & $1,500.00$ & 1,50 & $2,504.35$ & 2,50 & 3654.35 & 3,65 \\
\hline 2 & KM. PUTRI LAUT-07 & 64.2857 & 0,06 & 71.43 & 0,07 & $1,146.43$ & 1,14 & $4,054.29$ & 4,05 & 3555.36 & 3,55 \\
\hline 3 & KM. JERUSALEM & 3642.86 & 3,65 & $3,832.14$ & 3,83 & $2,535.71$ & 2,53 & $2,317.86$ & 2,32 & 1029 & 1,02 \\
\hline 4 & KM. MELSTESYE & 1093.46 & 1,09 & $1,100.00$ & 1,10 & $3,043.57$ & 3,05 & $2,201.07$ & 2,20 & 5143.71 & 5,15 \\
\hline 5 & KM. RATU ROSARI -01 & 571.429 & 0,57 & 607.14 & 0,60 & $1,651.79$ & 1,66 & $2,912.50$ & 2,92 & 1660.75 & 1,67 \\
\hline 6 & KM. AL - ANSHAR & 5218.97 & 5,22 & $5,318.97$ & 5,32 & $3,126.21$ & 3,12 & $1,608.97$ & 1,61 & 1642.76 & 1,65 \\
\hline 7 & KM. PUTRI VITA & 993.103 & 0,99 & 993.10 & 0,99 & $2,109.24$ & 2,10 & 163.45 & 0,16 & 4496.55 & 4,50 \\
\hline 8 & KM. ARDILAH - 03 & 4075.86 & 4,08 & $4,143.10$ & 4,14 & $1,933.79$ & 1,94 & $2,402.41$ & 2,40 & 6379.66 & 6,38 \\
\hline 9 & KM. SARI USAHA - 02 & 6606.9 & 6,60 & $6,901.72$ & 6,91 & $6,503.79$ & 6,51 & 870.69 & 0,87 & 931.034 & 0,93 \\
\hline 10 & KM. ALBAKOR & 2434.48 & 2,43 & $2,487.93$ & 2,49 & $2,476.21$ & 2,47 & 606.90 & 0,61 & 941 & 0,94 \\
\hline 11 & KM. ADAM PUTRA - 01 & 2448.28 & 2,44 & $2,511.03$ & 2,51 & $2,080.00$ & 2,08 & $1,982.76$ & 1,99 & 1030.24 & 1,03 \\
\hline 12 & KM. GENESARET - 03 & 360 & 0,36 & 428.33 & 0,42 & $4,692.73$ & 4,70 & $3,041.67$ & 3,05 & 1892.33 & 1,89 \\
\hline
\end{tabular}

Keterangan:

kapal dengan Produktivitas di atas standar $\geq 3,0$ (ditandai dengan huruf bold)

kapal dengan Produksinya dibawah standar < 3,0 (tidak ditandai dengan huruf bold) 


\section{KESIMPULAN}

Tren (perubahan) hasil tangkapan ikan TCT yang menggunakan kapal Purse Seine 20-30 GT di PPS Bitung berdasarkan analisis data dengan 12 kapal sebagai sampel didapatkan produktivitas menurut trip (produksi dibagi trip) menunjukkan bahwa hasil produksi TCT mengalami peningkatan untuk tahun 2011 hingga 2012, dan mengalami penurunan pada tahun 2013-2014. Sedangkan untuk produktivitas ikan TCT berdasarkan Kepmen KP No.61 tahun 2014 menunjukkan pada periode tahun 2011 - 2015 hasil yang didapatkan mengalami fluktuasi ditiap tahunnya.

\section{Ucapan Terima Kasih}

Penulis mengucapkan terima kasih pada pihak Pelabuhan Perikanan Samudra Bitung yang telah membantu dalam penyediaan data hasil tangkapan TCT yang digunakan dalam penelitian ini.

\section{DAFTAR PUSTAKA}

Adisanjaya N.N. 2011. Potensi, Produksi Sumberdaya Ikan di Perairan LautIndonesia dan Permasalahannya. EAFM Indonesia.Jakarta.

Direktorat Jenderal Pengolahan dan Pemasaran Hasil Perikanan. 2012. Statistik Ekspor Hasil Perikanan Menurut Komoditi Provinsi dan Pelabuhan Asal Ekspor 2012. Kementerian Kelautan dan Perikanan. Republik Indonesia.

Direktorat Jenderal Perikanan Tangkap. 2016. Laporan Statistik Pelabuhan Perikanan Samudera Bitung 2015. Kementerian Kelautan dan Perikanan. Kota Bitung

Dinas Kelautan dan Perikanan Kota Bitung. 2013. Dalam Laporan Tahunan Bitung Dalam Angka Kelautan dan Perikanan Dalam Angka Tahun 2013.

Keputusan Menteri Kelautan Dan Perikanan Republik Indonesia Nomor 61/KEPMEN KP/2014 tentang Produktivitas Kapal Penangkapan Ikan

Kuncoro, E. B., Wiharto, F. E..\& Ardi. 2009. Ensiklopedia Populer Ikan Air Laut. Yogjakarta.

Matsumoto, et al. 1984. Sinopsis of Biological Data on Skipjack Tuna, Katsuwonus Pelamis. NOAA Technical Report, FAO Fisheries Synopsis No. 136 Honolulu.

Nazir, M. 1993. Metode Penelitian. Ghali Indonesia. Jakarta. 622 hal.
Nontji, A., 2002. Laut nusantara. Penerbit Jembatan, Jakarta.

Nedelec. 2000. FISH LAMPS. Japanese Fishing Gear and Methods Textbook for Marine FisheriesResearch Course. Japan. (terhubung berkala) http:// fisheries.com/index.html (18 Oktober2010)

Pemerintah Kota Bitung. (2010). Sekilas Kota Bitung. http://www.bitungkota.go.id/index.php.

Punaji Setyosari. 2010. Metode Penelitian Pendidikan Dan Pengembangan. Jakarta: Kencana

Purwanto, 2003. Makalah Pengelolaan Sumberdaya Ikan. Disajikan Pada Workshop Pengkajian Sumberdaya Ikan, Jakarta 25 Maret 2003. Halaman 5.

Saanin, H. 1984. Taksonomi dan Kunci Identifikasi Ikan, Jilid I dan II. Bina Cipta, Bandung. 520 halaman.

Sinungan, Muchdarsyah. (1987). Produktivitas: Apa dan Bagaimana. PT Bina Akasara. Jakarta.

Subani,W dan H.R. Barus. 1989. Alat Penangkapan Ikan dan Udang Laut di Indonesia Jurnal Penelitian Perikanan Laut Nomor : 50 Tahun 1988/1989. Edisi Khusus. Jakarta : Balai Penelitian Perikanan Badan Penelitian dan Pengembangan Pertanian Departemen Pertanian

Saifuddin Azwar, 2004. Metode Penelitian, Cetakan V, Pustaka Pelajar, Yogyakarta.

Setyorini, Agus Suherman dan Imam Triarso, 2009. Analisis Perbandingan Produktivitas Usaha Penangkapan Ikan Rawai Dasar (Bottom Set Long Line) Dan Cantrang (Boat Seine) Di Juwana Kabupaten Pati.

Saputra, A., M. S. Sompie dan Manoppo, L. 2014. Analisis Tren Hasil Tangkapan Ikan Cakalang (Katsuwonus Pelamis) Dengan Alat Tangkap Purse Seine Dan Pole and Line (Studi Kasus Di Pelabuhan Perikanan Samudera Bitung). Jurnal Ilmu dan Teknologi Perikanan Tangkap 1(6): 204-208, Desember 2014 ISSN 2337. Program Studi Pemanfaatan Sumberdaya Perikanan, FPIK UNSRAT, Manado

Surur, F. 2010. Purse Seine. STP Press, Jakarta.

Tanjung, I. 2010. Peran Pangkalan Pendaratan Ikan (PPI) Kota Dumai dalam Mendukung aktivitas Penangkapan Ikan [Skripsi]. Bogor; Departemen Pemanfaatan Sumberdaya Perikanan. Fakultas Perikanan dan Ilmu Kelautan. Institut Petanian Bogor.

Umar, H. 2005. Metode Penelitian untuk Skripsi dan Tesis Bisnis. Jakarta: Rajagrafindo Persada.

Utomo, B.S.B dan F.R. Dewi. 2010. Kondisi dan Permasalahan Industri Pengolahan Cakalang di Bitung (Kasus Pengembangan Unit Pengolahan Ikan di Bitung). Laporan Hasil Penelitian. BBRPPBKP. Jakarta

Walpole, RE. 1992. Pengantar Statistika Edisi ke-3. Jakarta: PT. Gramedia Pustaka Utama. 515 halaman.

Zulham, A., A.H. Purnomo. (2010). Minapolitan (dari Konsep Menuju Implementasi). Balai Besar Riset Sosial Ekonomi dan Pengembangan Kelautan dan Perikanan. Kementerian Kelautan dan Perikanan. Jakarta

Zulham, A. 2011. Industri Perikanan Di Bitung. Buletin Sosek Kelautan dan Perikanan Vol. 6 No. 2, 2011. Balai Besar Penelitian Sosial Ekonomi Kelautan dan Perikanan. 